Brit. J. prev. soc. Med. (1976), 30, 213-218

\title{
Influence of family factors on asthma and wheezing during the first five years of life
}

\author{
S. R. LEEDER*, R. T. CORKHILL, L. M. IRWIG†, AND W. W. HOLLAND \\ Department of Community Medicine, St Thomas's Hospital Medical School, St Thomas's Hospital, London \\ J. R. T. COLLEY \\ Department of Community Health, Bristol
}

Leeder, S. R., Corkhill, R. T., Irwig, L. M., Holland, W. W., and Colley, J. R. T. (1970). British Journal of Preventive and Social Medicine, 30, 213-218. Influence of family factors on asthma and wheezing during the first five years of life. Family factors associated with the incidence of asthma and wheezing during childhood have been studied in a cohort of over 2000 children who, together with their families, were followed-up for five years. Episodes of wheezing not regarded by the parents as asthma had a different pattern of association with family factors to that found for asthma. The outcome of the two conditions in terms of ventilatory function at the age of five years was also different, in that children with a history of asthma had a lower peak expiratory flow rate than did children with a history of non-asthmatic wheezing.

Attacks of wheezing are common events in childhood in the United Kingdom. Two studies showed that some $20 \%$ of children received attention from their general practitioner for at least one episode of wheezing during their first decade (Fry, 1961; Goodall, 1958). The relationship between attacks of wheezing accompanying acute lower respiratory infection, sometimes termed wheezy bronchitis, and wheezing precipitated by allergens, emotional stress, or exercise is particularly difficult to define (British Medical Journal, 1973; Gordis, 1973). It is likely that in some cases episodes of wheezing mark the beginning of chronic bronchial asthma (Williams and McNicol, 1969; Gandevia et al., 1973). In this paper we report observations on different family factors associated either with episodes of wheezing considered by parents not to be asthma, and with what the parents termed asthma, in over 2000 children who were studied, together with their families, until the children were five years old. We reasoned that if all attacks of wheezing were in

- Present address: Department of Medicine, McMaster University Medical Centre, Hamilton, Ontario, Canada L8S 4J9.

†resent address: National Research Institute for Occupational Diseases, P.O. Box 4788, Johannesburg 200. Republic of South Africa. reality mild attacks of asthma, they would be associated with the same family factors as frank asthma.

\section{Methods AND MATERIALS}

The methods and materials pertaining to this study are described in the preceding paper.

\section{RESULTS}

By the age of five years, one or more episodes of asthma had been reported in $3.4 \%$ of boys and $2.9 \%$ of girls. Wheezy, whistling, or chesty episodes without asthma were reported in $22.5 \%$ of boys and $20.7 \%$ of girls.

Episodes of wheezing rather than asthma were associated with a history of bronchitis or pneumonia in children during their first year of life, $41 \cdot 2 \%$ of children with a history of bronchitis or pneumonia in the first year subsequently suffered from wheezing, compared with $19.2 \%$ of children without bronchitis or pneumonia (Table I: relative risk for wheeze is $2 \cdot 15)$. Asthma was not so strongly associated with bronchitis or pneumonia in the first year, $4.3 \%$ of children with this history suffered from subsequent 
TABLE I

INCIDENCE PER 100 INDEX CHILDREN OF WHEEZING* IN FIRST FIVE YEARS OF LIFE BY BRONCHITIS OR PNEUMONIA IN FIRST YEAR, AND BY PARENTAL ASTHMA-WHEEZE

\begin{tabular}{|c|c|c|c|c|c|}
\hline & & \multicolumn{4}{|c|}{ Parental Asthma.Wheeze } \\
\hline & & Neither & One & Both & Total \\
\hline \multirow{3}{*}{$\begin{array}{l}\text { Bronchitis or pneumonia } \\
\text { in the first year }\end{array}$} & & $\begin{array}{c}17 \cdot 7 \\
(1333)\end{array}$ & $\begin{array}{l}24 \cdot 2 \\
(421)\end{array}$ & $\begin{array}{l}16 \cdot 0 \\
(50)\end{array}$ & $\begin{array}{l}19 \cdot 2 \\
(1804)\end{array}$ \\
\hline & Yes & $\begin{array}{l}37 \cdot 7 \\
(138)\end{array}$ & $\begin{array}{l}46 \cdot 8 \\
(77)\end{array}$ & $\begin{array}{c}44 \cdot 4 \\
(18)\end{array}$ & $\begin{array}{l}41 \cdot 2 \\
(233)\end{array}$ \\
\hline & Total & $\begin{array}{l}19 \cdot 6 \\
(1471)\end{array}$ & $\begin{array}{l}27 \cdot 7 \\
(498)\end{array}$ & $\begin{array}{l}23 \cdot 5 \\
(68)\end{array}$ & $\begin{array}{l}21 \cdot 7 \\
(2037) \dagger\end{array}$ \\
\hline
\end{tabular}

Populations in parentheses

* Wheezing excludes children who had asthma.

†Total excludes 96 index children with missing first, third, fourth, and fifth year data and an additional 16 with missing initial data on paren $t ?$ pairs.

asthma, compared with $3.0 \%$ of children without this history (Table II: relative risk for asthma is $1 \cdot 41)$. In children with one parent with a history of asthma-wheeze, the incidence of asthma was $5.4 \%$ compared with $2 \cdot 5 \%$ of children whose parents were both free of asthma-wheeze. The incidence of wheezing was also higher in children with one parent with a history of asthma-wheeze $(27 \cdot 7 \%)$ compared with children of parents without such a history $(19.6 \%)$. However, the risk was no greater, and sometimes less, if both parents had asthma-wheeze. This inconsistent trend may partly be a consequence of some rates being based on small numbers (Tables I and II). There was no consistent relationship between smoking and cough-phlegm in the parents and asthma in the children, although conclusions are limited once more by small numbers of children with asthma in some cells (Table III). By contrast, wheezing was consistently more common in children when their parents smoked or suffered from cough-phlegm (Table IV).
Asthma was reported more commonly in childreniv of parents in the upper social than in children of $\vec{\omega}$ lower social class parents (Table V). However, the? rates were based on small numbers and the sociel class gradients were not wholly consistent at all age $7 ; ;_{\mathbb{D}}$ for example, the lowest incidence occurred ${ }^{\circ}$ 他 children up to the age of three years with parengis? from social class III. Wheezing was more commond in children of lower social class parents. Area off $\overrightarrow{0}$ residence had no influence on the incidence of asthraa or wheezing.

As some of the family factors examined in the preceding tables were themselves interrelated, it was difficult to assess the influence of each individualo factor upon the incidence of asthma or wheezing in $\frac{\mathscr{O}}{\mathrm{O}}$ the index children. To investigate these relationships,, two logistic models were fitted to the data, one with $\overrightarrow{\overrightarrow{0}}$ the incidence of asthma in the index children as the 3 outcome variable, and the other with the incidence of wheezing as the outcome variable. The independent ${ }^{\circ}$ variables included in both models were parentale

TABLE II

INCIDENCE PER 100 INDEX CHILDREN OF ASTHMA* IN FIRST FIVE YEARS OF LIFE BY BRONCHITIS OR PNEUMONIA IN FIRST YEAR, AND BY PARENTAL ASTHMA-WHEEZE

\begin{tabular}{|c|c|c|c|c|c|}
\hline & & \multicolumn{4}{|c|}{ Parental Asthma-Wheeze } \\
\hline & & Neither & One & Both & Total \\
\hline \multirow{3}{*}{$\begin{array}{l}\text { Bronchitis or pneumonia } \\
\text { in the first year }\end{array}$} & & $\begin{array}{l}2 \cdot 3 \\
(1333)\end{array}$ & $\begin{array}{c}5.5 \\
(421)\end{array}$ & $\begin{array}{l}2 \cdot 0 \\
(50)\end{array}$ & $\begin{array}{c}3.0 \\
(1804)\end{array}$ \\
\hline & Yes & $\begin{array}{l}3.6 \\
\text { (138) }\end{array}$ & $\begin{array}{l}5 \cdot 2 \\
(77)\end{array}$ & $\begin{array}{l}5.6 \\
(18)\end{array}$ & $\begin{array}{c}4 \cdot 3 \\
(233)\end{array}$ \\
\hline & Total & $\begin{array}{c}2 \cdot 5 \\
(1471)\end{array}$ & $\begin{array}{c}5.4 \\
(498)\end{array}$ & $\begin{array}{l}2.9 \\
(68)\end{array}$ & $\begin{array}{c}3 \cdot 2 \\
(2037) \dagger\end{array}$ \\
\hline
\end{tabular}


TABLE III

INCIDENCE PER 100 INDEX CHILDREN OF ASTHMA* IN FIRST FIVE YEARS BY PARENTAL COUGH-PHLEGM AND SMOKING HABITS

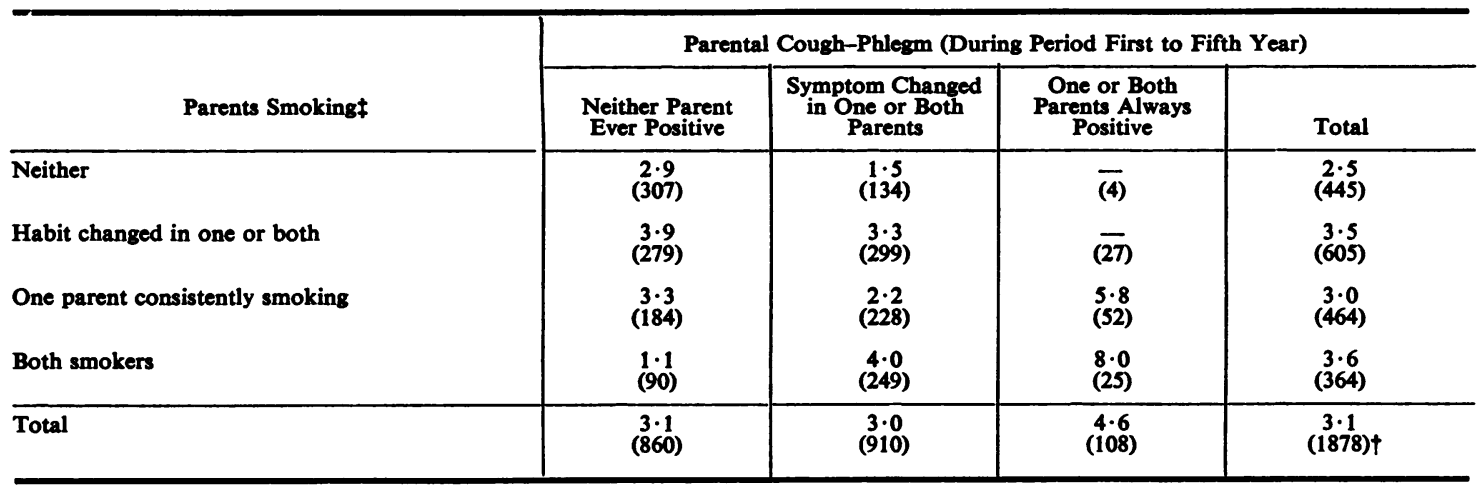

Populations in parentheses.

*Asthma includes children who may have wheezed as well.

†Total excludes 72 index children with missing third, fourth, and fifth year data and an additional 199 with missing first to fifth year data on parent pairs.

¥Considered over the full five years of the study.

TABLE IV

INCIDENCE PER 100 INDEX CHILDREN OF WHEEZING* IN FIRST FIVE YEARS BY PARENTAL COUGH-PHLEGM AND SMOKING HABITS

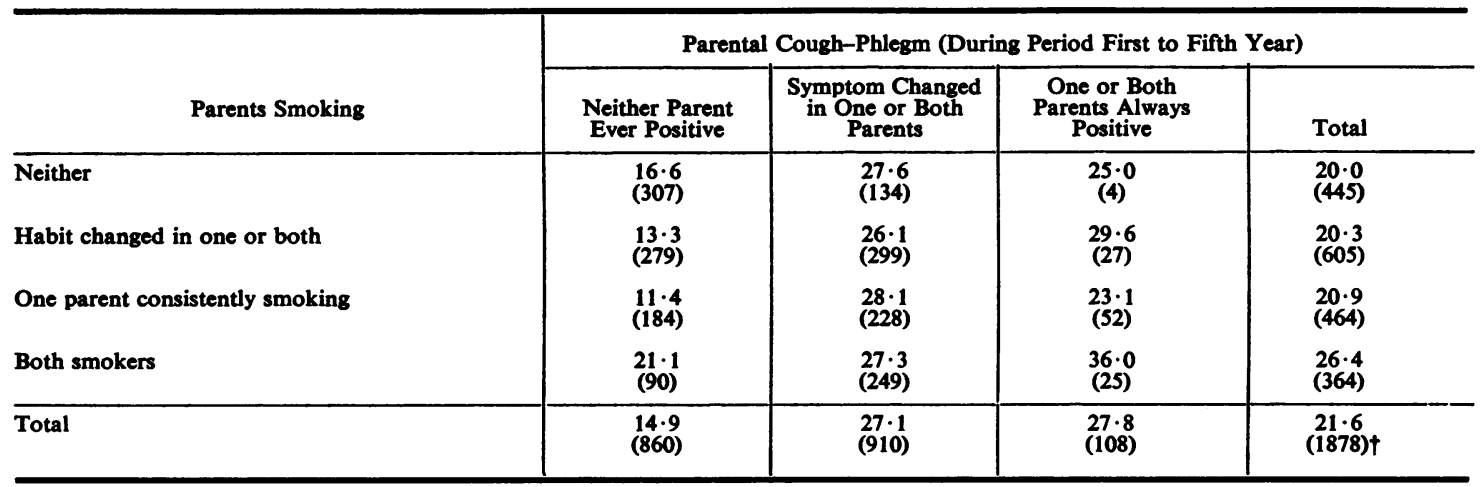

Populations in parentheses.

* Wheezing excludes children who had asthma.

†Total excludes 72 index children with missing third, fourth, and fifth year data and an additional 199 with missing first to fifth year data on parent pairs.

\section{TABLE V}

INCIDENCE PER 100 INDEX CHILDREN OF ASTHMA OR WHEEZING* DURING FIRST FIVE YEARS BY PARENTAL SOCIAL CLASS AT FIFTH YEAR

\begin{tabular}{|c|c|c|c|c|c|c|c|}
\hline \multirow{3}{*}{$\begin{array}{l}\text { Illness in Children of Parents } \\
\text { According to Social Class }\end{array}$} & \multicolumn{6}{|c|}{ Age in Years } & \multirow[b]{3}{*}{ Population } \\
\hline & \multicolumn{2}{|c|}{ By Age Three } & \multicolumn{2}{|c|}{ By Age Four } & \multicolumn{2}{|c|}{ By Age Five } & \\
\hline & Asthma & Wheezing & Asthma & Wheezing & Asthma & Wheezing & \\
\hline $\begin{array}{l}\text { Social class } \\
\text { I and II }\end{array}$ & $2 \cdot 0$ & $17 \cdot 2$ & $3 \cdot 1$ & $19 \cdot 2$ & $4 \cdot 0$ & $20 \cdot 8$ & 751 \\
\hline III & $1 \cdot 0$ & $20 \cdot 2$ & $2 \cdot 1$ & $22 \cdot 3$ & $2 \cdot 7$ & $23 \cdot 5$ & 997 \\
\hline IV and $V$ & $1 \cdot 4$ & $21 \cdot 2$ & $1 \cdot 8$ & $24 \cdot 5$ & $2 \cdot 5$ & $27 \cdot 3$ & 278 \\
\hline Unknown & $3 \cdot 9$ & $13 \cdot 7$ & $3 \cdot 9$ & $17 \cdot 7$ & $3 \cdot 9$ & $17 \cdot 7$ & 51 \\
\hline Total & $1 \cdot 5$ & $19 \cdot 1$ & $2 \cdot 5$ & $21 \cdot 3$ & $3 \cdot 2$ & $22 \cdot 9$ & $2077 \dagger$ \\
\hline
\end{tabular}

*Asthma includes children who may have wheezed as well; wheezing excludes children who had asthma.

tTotal excludes 72 index children with missing third, fourth, and fifth year data. 
smoking, parental cough-phelgm, parental asthmawheeze, number of siblings and their history of bronchitis or pneumonia and of asthma-wheeze, the sex of the index child, history of bronchitis or pneumonia in the first year of life, social class of the father when the child was aged five years, and area of residence.

In asthma, a history of parental asthma-wheeze was the only statistically significant factor. However, with wheezing, parental cough-phlegm and bronchitis or pneumonia during the first year of life of the child were both found to be statistically significant. The model was then refitted with these two factors alone as independent variables. The crude and adjusted incidence rates using this model are presented in
Table VI, which shows that bronchitis or pneumonia尺 during the first year of life had the greater effect upons the incidence of wheezing.

The influence of a history of asthma or wheezing on peak expiratory flow rate at five years was? examined in those children for whom these data were? available (Table VII). Peak expiratory flow rates were $\overline{\text { 으․ }}$ adjusted for differences in sitting height at age five $\frac{\Phi}{\vec{T}}$ years. Children with a history of both asthma and $\mathbb{\complement}$ bronchitis or pneumonia had a significantly loweros mean peak expiratory flow rate than those with $a_{0}$ history of bronchitis or pneumonia alone; a differenceof $17.4 \%(P<0.001)$. Mean peak flow rates in $\vec{\omega}$ children with a history of wheezing and bronchitis? or pneumonia did not differ significantly from thoses?

TABLE VI

CRUDE AND ADJUSTED INCIDENCE RATES PER 100 CHILDREN OF WHEEZING* FOR LEVELS OF EACH FACTOR WITHË ESTIMATES OF THEIR EFFECTS

\begin{tabular}{|c|c|c|c|c|c|}
\hline \multirow[b]{2}{*}{ Factor and Level } & \multirow[b]{2}{*}{ Crude Incidence Rate } & \multirow{2}{*}{$\begin{array}{c}\text { Adjusted } \\
\text { Incidence Rate }\end{array}$} & \multicolumn{3}{|c|}{ Significance of the Factor in the Model } \\
\hline & & & $\chi^{2}$ & df & $\mathbf{P}$ \\
\hline $\begin{array}{l}\text { Parental cough-phlegm } \\
\text { Neither }\end{array}$ & $17 \cdot 7$ (1263) & $17 \cdot 6$ & $22 \cdot 69$ & 2 & $<0.0005$ \\
\hline One & $27 \cdot 2 \quad(670)$ & $26 \cdot 3$ & & & \\
\hline Both & $34 \cdot 6 \quad(78)$ & $30 \cdot 3$ & & & \\
\hline $\begin{array}{l}\text { Bronchitis or pneumonia in } \\
\text { the first year } \\
\text { No }\end{array}$ & $18 \cdot 9(1781)$ & $18 \cdot 8$ & $43 \cdot 63$ & 1 & $<0.0005$ \\
\hline Yes & $41 \cdot 3 \quad(230)$ & $39 \cdot 4$ & & & \\
\hline Total & $21 \cdot 5(2011) t$ & - & - & 一 & 一 \\
\hline
\end{tabular}

Populations in parentheses.

* Wheezing excludes children who had asthma.

†Total excludes 96 index children with missing first, third, fourth, and fifth year data and an additional 42 with missing initial or first year data? on parent pairs.

TABLE VII

MEAN PEAK EXPIRATORY FLOW RATES IN CHILDREN AGED FIVE YEARS, BY HISTORY OF ASTHMA, WHEEZING BRONCHITIS, OR PNEUMONIA

\begin{tabular}{|c|c|c|c|c|c|}
\hline \multirow[b]{2}{*}{ Symptom Group } & \multirow[b]{2}{*}{ Mean PEFR† } & \multirow[b]{2}{*}{ Population } & \multirow{2}{*}{$\begin{array}{l}\text { Standard Error } \\
\text { of the Mean }\end{array}$} & \multicolumn{2}{|c|}{$\begin{array}{l}\text { Significance of Difference } \\
\text { Between Means of Groups With and } \\
\text { Without Symptoms }\end{array}$} \\
\hline & & & & $t$ & $\mathbf{P}$ \\
\hline $\begin{array}{l}\text { Nil } \\
\text { Asthma without bronchitis or pneumonia } \\
\text { Wheezing without bronchitis or pneumonia } \\
\text { Asthma with bronchitis or pneumonia } \\
\text { Wheezing with bronchitis or pneumonia } \\
\text { Bronchitis or pneumonia only }\end{array}$ & $\begin{array}{l}151 \cdot 5 \\
149 \cdot 2 \\
118 \cdot 6 \\
140 \cdot 3 \\
143 \cdot 5\end{array}$ & $\begin{array}{r}292 \\
3 \\
40 \\
10 \\
33 \\
76\end{array}$ & $\begin{array}{l}1 \cdot 5 \\
4 \cdot 1 \\
8 \cdot 2 \\
4 \cdot 5 \\
3 \cdot 0\end{array}$ & $\begin{array}{l}0 \cdot 51 \\
3 \cdot 95 \\
2 \cdot 34 \\
2 \cdot 38\end{array}$ & $\begin{array}{c}0.6<P<0.7 \\
P \text { P }<0.001 \\
0.01<P<0.02 \\
0.01<P<0.02\end{array}$ \\
\hline Total & - & $454 t$ & - & - & - \\
\hline
\end{tabular}

*Asthma includes children who may have wheezed as well; wheezing excludes children who had asthma.

tTotal excludes 4 index children with successful flow rate measurements at age five years but with missing first to fourth year data. The remaining

1691 children were not measured at age five years.

$\neq$ Litres/min, adjusted for sitting height at age five years. 
with a history of bronchitis or pneumonia alone. The $\mathbf{4 0}$ children with a history of wheezing alone had peak flow rates similar to those of children without a history of asthma, wheezing, bronchitis, or pneumonia.

\section{Discussion}

Episodes of wheezing, 'whistling' or 'chestiness' not termed asthma by parents occurred much more commonly (in $21.7 \%$ of children) than asthma $(3.2 \%)$ by the age of five years. Wheezing episodes were closely associated with bronchitis and pneumonia occurring during the first year. Wheezing was also associated with parental cough-phlegm and smoking as was bronchitis or pneumonia in the first year (Leeder et al., 1976). This suggests that at least some of the environmental factors associated with bronchitis or pneumonia may also be important in the development of wheezing episodes in later childhood. Alternatively, genetic factors associated with bronchitis or pneumonia in the first year may also predispose to wheezing in later childhood. Damage to airways caused by bronchitis or pneumonia in early childhood may also make children more liable to wheeze subsequently.

While episodes of asthma in the first five years of life also showed an association with parental history of asthma-wheeze (as did episodes of wheezing not termed asthma) there is little relationship between asthma in the first five years and other family, social, or environmental factors.

In this study, the parents' account of asthma and wheezing in their children was used to define these illnesses. Despite the uncertainties implicit in using parentally reported data, asthma and wheezing were, as discussed, associated with different family factors. Also, the effects of asthma and wheezing on peak expiratory flow rates at the age of five years were different. Children with a history of asthma had lower peak expiratory flow rates at the age of five than the children with a history of wheezing alone. In asthma adequate treatment can often reverse much of the airways obstruction. The low peak expiratory flow rate at the age of five we found in children with a history of asthma may indicate the need for vigorous bronchodilator therapy. Alternatively, this deficit may reflect irreversible airways obstruction (Cade and Pain, 1973). More concerted treatment in the first five years of life may have prevented its development. Whatever the potential for the reversal of the decreased peak expiratory flow rate found in children with a history of asthma, it appears that the parents' account differentiated between important and unimportant illness, according to whether they termed it asthma or wheezing.

The incidence rates for asthma and wheezing obtained in studies of children clearly depend upon how these two conditions are defined and the populations in which surveys are conducted. In a study of Kent schoolchildren, using similar methods to those used in this study, Hamman, Halil, and Holland (1975), found comparable rates of asthma by the age of 11 years to those that we found by the age of five years. Similar incidence rates for asthma were found in a study of schoolchildren in Birmingham (Smith, 1961).

Asthma was reported more commonly in children of upper class parents, whereas the reverse was true of wheezing. These social class trends could reflect differences in reporting behaviour among parents of different social classes. More parents in social classes I and II may report asthma rather than wheezing episodes when confronted with essentially the same illness in their children. Alternatively, there could be a real difference in the social class distribution of asthma. Hamman et al. (1975) found a similar trend to the one described in this paper while Dawson et al. (1969) in a study in Aberdeen, Scotland, found a social class trend in asthma incidence contrary to ours.

The incidence of wheezing may prove to be more modifiable than that of asthma by changing environmental factors, as attacks of wheezing were closely associated with bronchitis and pneumonia during the first year of life. Bronchitis and pneumonia in the first year have, in turn, been shown to be associated with such factors as parental smoking habits (Colley, Holland, and Corkhill, 1974). Thus, efforts to prevent bronchitis and pneumonia during the first year of life may also reduce the incidence of wheezing and of other chest illnesses in later childhood.

The syndromes of lower respiratory illness in childhood remain poorly defined and it is clear that the precision of diagnosis of these illnesses requires improvement before more effective treatment can be given to the children who require it. On the basis of the epidemiological evidence presented here, it seems most unlikely that all forms of the more frequent lower respiratory illness in childhood are simply manifestations of a single common disorder. There may well be common features in aetiology and natural history between conditions such as asthma and bronchitis, but this is not a good reason to use these terms interchangeably. This is especially important when strategies for prevention of one or other condition are being considered. 
This study was supported in part by the Department of Health and Social Security. Dr S. R. Leeder was in receipt of a National Health and Medical Research Council (Australia) Clinical Sciences Fellowship. It was undertaken in conjunction with the London Borough of Harrow Health, Welfare, and Children's Department. We should particularly like to thank Miss I. Watson and Miss M. S. Hirschhorn, Superintendent Health Visitors, and their staff, and Mr G. Phipps, Senior Administrative Assistant in the Personnel Health Section and his staff, and all other individuals who took part for their help and co-operation.

We thank Miss C. Astbury, Miss S. Brenner, Miss P. Cox, Miss J. Dale, Miss H. Polak, and Miss A. Witts for maintaining the records and doing most of the field work, Mr Andy Thomson for his help with data processing, and Mrs Susie Gilderdale and Miss Bridget McClune for their assistance in the preparation of this paper.

Requests for reprints: R. T. Corkhill, Lecturer in Medical Statistics, Department of Community Medicine, St Thomas's Hospital Medical School, London SE1 7EH.

\section{REFERENCES}

British Medical Journal (1973). Leading article. Asthma and wheezy bronchitis in childhood. Brit. med. J., 4, 749.

Cade, J. F. and Pain, M. C. F. (1973). Pulmonary function during clinical remission of asthma: how reversible is asthma? Aust. N.Z. J. Med., 3, 545.

Colley, J. R. T., Holland, W. W., and Corkhill, R. T. (1974). Influence of passive smoking and parental phlegm on pneumonia and bronchitis in early childhood. Lancet, 2, 1031.
Dawson, B., Horobin, G., IllsLey, R., and Mrtchel R. (1969). A survey of childhood asthma in Aberdeet Lancet, 1, 827.

FRY, J. (1961). The Catarrhal Child. Butterworth $\overrightarrow{\vec{G}}$ London.

Gandevia, B., Hall, G. J. L., Silverstone, he and GIBson, H. B. (1973). Respiratory disorders seven-year-old children in Tasmania. Proceedings $f$ the Sixth International Scientific Meeting of the International Epidemiological Association, Primosten 1971. Savremena Admininstracija, Belgrade.

Goodall, J. F. (1958). The natural history of commong respiratory infection in children and some principle in its management: III Wheezy children. J. of roy. Co. of gen. Practit., 1, 51.

GoRDIs, L. (1973). Epidemiology of chronic lung diseases children. Johns Hopkins Press, Baltimore.

Hamman, R. F., Halil, T., and Holland, W. $\vec{W}$ (1975). Asthma in schoolchildren: demographis associations and peak expiratory flow rates compgred in children with bronchitis. Brit. J. prev. soc. Med 29, 228.

LeEDER, S. R., CORKHILl, R., IRWIG, L. M., Holl R W. W., and CoLLEY, J. R. T. (1976). Influence of family factors on the incidence of lower respiratory illgess during the first year of life. Brit J. prev. soc. Bited 30, 203.

SMITH, J. M. (1961). Prevalence and natural history asthma in schoolchildren. Brit. med. J., 1, 711.

Williams, H. and McNicol, K. N. (1969). Prevalence natural history, and relationship of wheezy bronchit and asthma in children. An epidemiological studg Brit. med. J., 4, 321. 